\title{
Anti-bacterial property and anti-nutritional contents of five wild fruits of Assam, India
}

\author{
Anuck Islary ${ }^{1}$, Jatin Sarmah², Sanjay Basumatary ${ }^{3 *}$ \\ ${ }^{1}$ Department of Food Engineering and Technology, Central Institute of Technology, Kokrajhar, India. \\ ${ }^{2}$ Department of Biotechnology, Bodoland University, Kokrajhar, India. \\ ${ }^{3}$ Department of Chemistry, Bodoland University, Kokrajhar, India.
}

\begin{tabular}{l}
\hline ARTICLE INFO \\
\hline Received on: $10 / 09 / 2018$ \\
Accepted on: $11 / 11 / 2018$ \\
Available online: $30 / 12 / 2018$ \\
\\
\hline Key words: \\
Anti-bacterial activity, \\
anti-nutritional content, MBC, \\
MIC, wild edible fruits.
\end{tabular}

\section{INTRODUCTION}

Wild edible fruits are considered as excellent sources of nutrients and various bioactive compounds; especially, the antioxidant and anti-bacterial compounds. These fruits have received worldwide increasing attention because of their important contributions to the health of rural communities. It is well known that most of the drugs in present days are of natural products and their derivatives. Antibacterials of plant origin have immense therapeutic potentials and are effective in the treatment of infectious diseases than synthetic antimicrobials which have adverse effects (Brandi et al., 2006). Polyphenols from plants possess several benefits including antimicrobial properties against pathogenic and spoilage microbes and

\section{${ }^{*}$ Corresponding Author}

Sanjay Basumatary, Department of Chemistry, Bodoland University, Kokrajhar, India.E-mail: waytosanjay12@gmail.com variations in the chemical compositions of these compounds lead to remarkable differences in their antimicrobial activity (Savoia, 2012). Plant-derived antimicrobials have been recognized for centuries, but only scientifically confirmed in the last 30 years (Gyawali et al., 2012). Natural antimicrobials play a significant role in food control by preventing microbial contamination or growth and by extending shelf life due to the removal of undesirable pathogens (Lanciotti et al., 2004). In addition to the nutrients and bioactive compounds, anti-nutrients are also naturally occurring organic compounds found in plants which in the intake of excess play some adverse roles (Akindahunsi et al., 2005). They reduce the maximum utilization of nutrients especially vitamins, minerals, and proteins, and thus prevent the optimal exploitation of the nutrients present in a food and decrease the nutritive value. Anti-nutrients are not always harmful even though they lack nutritive values. Anti-nutrients are beneficial for human health if consumed at appropriate amounts, and can prevent diseases including cancers and coronary diseases (Ugwu et al., 2006). 
The objective of the present study is to investigate the anti-bacterial properties of five wild edible fruits, viz., Grewia sapida, Ottelia alismoides, Aporosa dioica, Antidesma bunius, and Eugenia operculata against strains of gram-positive and gram-negative bacteria and determine the anti-nutritional contents of these wild fruits.

\section{MATERIALS AND METHODS}

\section{Collection of sample}

Wild fruits

Fresh fruits of G. sapida, A. bunius, and E. operculata were collected in April 2015 from Chirang district of Assam (India) whereas the fresh fruits of $A$. dioica and $O$. alismoides were obtained in April and October 2015, respectively, from Kokrajhar district of Assam (India). The plants were authenticated at Botanical Survey of India, Meghalaya (Ref. No. BSI/ERC/Tech./Plant Iden./2015/211, Dated 25-06-2015) and Department of Botany, Bodoland University, Assam (Collection No. 501 and 502).

\section{Bacterial strains}

Two strains of gram-positive bacteria (Staphylococcus aureus $\mathrm{MTCC}-7443$; MTCC = microbial type culture collection and Bacillus cereus MTCC-430) and two strains of gramnegative bacteria (Escherichia coli MTCC-40 and Proteus vulgaris MTCC-7299) were obtained from Institute of Microbial Technology (IMTECH), Chandigarh, India for the study of the anti-bacterial activity of fruit extracts.

\section{Extraction of wild fruits}

The collected fruits were washed properly with distilled water followed by freeze drying for 72 hours and milling to a fine powder using a grinder, which were then kept in the airtight container. For the anti-bacterial study, the powdered sample was extracted with methanol using 1:10 ratio $(\mathrm{w} / \mathrm{v})$ by stirring vigorously at a normal temperature for 72 hours. The mixture was filtered using Whatman No. 1 filter paper and evaporated using Buchi Rotavapor (R-215, Switzerland) at $40^{\circ} \mathrm{C}$. The dried extract was kept in the plastic container at $4^{\circ} \mathrm{C}$ for analysis.

\section{Determination of anti-bacterial activity of fruit extract}

The anti-bacterial activity of each fruit extract was determined using the disc diffusion method (Jorgensen et al., 2007) with a slight modification. The methanol extract (100 mg) was dissolved in $2 \mathrm{ml}$ of dimethyl sulfoxide and sterilized through a membrane filter $(0.22 \mu \mathrm{m})$. It was then diluted to different concentration $(10,20,30 \mathrm{mg} / \mathrm{ml})$ and then $5 \mu \mathrm{l}$ was loaded over 6-mm diameter of sterilized filter paper discs. After that $10-15 \mathrm{ml}$ of Mueller-Hinton agar medium was poured into sterilized Petridishes and allowed to solidify for 15 minutes followed by addition of $100 \mu \mathrm{l}$ of bacterial culture on top of the plate, spread with sterile L-loop and allowed to dry for few minutes. The sterile filter paper disc loaded with different concentrations of fruit extract was placed on the top of Mueller-Hinton agar plates and allowed to incubate for 24 hours. Escherichia coli and S. aureus were incubated at $37^{\circ} \mathrm{C}$ and $P$. vulgaris and B. cereus were incubated at $27^{\circ} \mathrm{C}$. Filter paper disc loaded with $30 \mu \mathrm{g} / \mathrm{ml}$ of amoxicillin was taken as a positive control. Filter paper disc soaked in sterile distilled water and DMSO was taken as a negative control. The inhibition zones were measured by vernier calliper and the diameter of inhibitions were expressed in millimetre $(\mathrm{mm})$.

\section{Determination of minimum inhibitory concentration and} minimum bactericidal concentration

The minimum inhibitory concentration (MIC) and minimum bactericidal concentration (MBC) in the methanol extracts of fruits were determined according to the reported protocol of Kitzberger et al. (2007).

\section{Determination of anti-nutritional contents}

The powdered samples were investigated for antinutritional contents. Tannin content was evaluated as a catechin equivalent following vanillin- $\mathrm{HCl}$ method (Price et al., 1978). Oxalate content was determined by the titration method described by Day and Underwood (1986). Saponin content was estimated following the gravimetric method described by Obadoni and Ochuko (2001). Phytate content was evaluated according to the procedure reported by Vaintraub and Lapteva (1988). The procedure described by Griffiths (2000) was followed for the determination of alkaloid contents.

\section{Statistical analysis}

The experiments for anti-nutritional contents were performed for three replicates and the results were represented in terms of mean \pm standard deviation. OriginPro 8.5 software (MA 01060, OriginLab Corporation, Northampton, MA, USA) was used for the statistical analysis and executed by the one-way analysis of variance $t$-test at $p<0.05$.

\section{RESULTS AND DISCUSSION}

\section{Anti-bacterial activity of fruits extract}

Anti-bacterial activities in the methanol extracts of five wild edible fruits were studied by disc diffusion method at different concentrations $(10,20$, and $30 \mathrm{mg} / \mathrm{ml})$ against four bacterial strains, viz., two gram-positive bacteria (B. cereus and $S$. aureus) and two gram-negative bacteria (E. coli and $P$. vulgaris). All the fruit extracts showed anti-bacterial activities against bacterial strains and the results in terms of zone of inhibition of bacterial growth are presented in Table 1. In this study, the fruit extracts showed a comparatively smaller zone of inhibitions in comparison to the standard antibiotics. The largest zone of inhibition $(16 \mathrm{~mm})$ has been recorded against $E$. coli and $P$. vulgaris at $30 \mathrm{mg} / \mathrm{ml}$ concentration in the methanolic extracts of $O$. alismoides and $G$. sapida, respectively. Eugenia operculata indicated inhibition zones between $7 \mathrm{~mm}(10 \mathrm{mg} / \mathrm{ml})$ and $13 \mathrm{~mm}(30 \mathrm{mg} / \mathrm{ml})$ and showed the minimum activity of $7 \mathrm{~mm}(10 \mathrm{mg} / \mathrm{ml})$ against $B$. cereus. But in the other four fruits studied, no activity was observed at the lower concentration $(10 \mathrm{mg} / \mathrm{ml})$ against $B$. cereus. In all the tested bacteria, $G$. sapida fruits showed growth inhibition zones between $9 \mathrm{~mm}$ $(20 \mathrm{mg} / \mathrm{ml})$ and $16 \mathrm{~mm}(30 \mathrm{mg} / \mathrm{ml})$ but no activity was observed at $10 \mathrm{mg} / \mathrm{ml}$. Growth inhibition zones observed in $O$. alismoides fruit against $B$. cereus and $P$. vulgaris at $30 \mathrm{mg} / \mathrm{ml}$ were 10 and $9 \mathrm{~mm}$, respectively. However, no activities were noted at 10 and 
Table 1. Anti-bacterial activities of methanol extracts of fruits against four bacterial strains.

\begin{tabular}{|c|c|c|c|c|c|c|c|}
\hline \multirow[b]{2}{*}{ Sample } & \multicolumn{4}{|c|}{ Zone of inhibition at different concentration $(\mathrm{mm})$} & \multirow{2}{*}{$\begin{array}{c}\text { MIC } \\
(\mathrm{mg} / \mathrm{ml})\end{array}$} & \multirow{2}{*}{$\begin{array}{c}\text { MBC } \\
(\mathrm{mg} / \mathrm{ml})\end{array}$} & \multirow[b]{2}{*}{ Bacterial strains } \\
\hline & $\begin{array}{c}10 \\
\mathrm{mg} / \mathrm{ml}\end{array}$ & $\begin{array}{c}20 \\
\mathrm{mg} / \mathrm{ml}\end{array}$ & $\begin{array}{c}30 \\
\mathrm{mg} / \mathrm{ml}\end{array}$ & $\begin{array}{c}\text { Amoxicillin } \\
(30 \mu \mathrm{g} / \mathrm{ml})\end{array}$ & & & \\
\hline G. sapida & 0 & 9.5 & 11 & 23 & 15 & $<30$ & B. cereus \\
\hline A. bunius & 0 & 0 & 13 & 28 & $<30$ & $<30$ & \\
\hline E. operculata & 7 & 9 & 13 & 23 & 7.5 & 15 & \\
\hline A. dioica & 0 & 10 & 13 & 27 & 15 & $<30$ & \\
\hline O. alismoides & 0 & 0 & 10 & 26 & $<30$ & $<30$ & \\
\hline G. sapida & 0 & 9 & 11 & 25 & 15 & $<30$ & S. aureus \\
\hline A. bunius & 0 & 9 & 14 & 26 & 15 & $<30$ & \\
\hline E. operculata & 9 & 10 & 14 & 28 & 7.5 & 15 & \\
\hline A. dioica & 9.5 & 12 & 14 & 23 & 7.5 & 15 & \\
\hline O. alismoides & 9 & 10 & 12 & 29 & 7.5 & 15 & \\
\hline G. sapida & 0 & 12 & 14 & 30 & 15 & 15 & E. coli \\
\hline A. bunius & 0 & 0 & 15 & 27 & $<30$ & $<30$ & \\
\hline E. operculata & 0 & 0 & 12 & 28 & $<30$ & $<30$ & \\
\hline A. dioica & 0 & 8 & 13 & 26 & 15 & $<30$ & \\
\hline O. alismoides & 8 & 12 & 16 & 29 & 7.5 & 15 & \\
\hline G. sapida & 0 & 14 & 16 & 28 & 15 & 15 & P. vulgaris \\
\hline A. bunius & 0 & 8 & 13 & 24 & 15 & $<30$ & \\
\hline E. operculata & 0 & 0 & 13 & 25 & $<30$ & $<30$ & \\
\hline A. dioica & 0 & 12 & 14 & 28 & 15 & 15 & \\
\hline O. alismoides & 0 & 0 & 9 & 22 & $<30$ & $<30$ & \\
\hline
\end{tabular}

$20 \mathrm{mg} / \mathrm{ml}$ of $O$. alismoides fruit against $B$. cereus and $P$. vulgaris. At the concentration of $10 \mathrm{mg} / \mathrm{ml}$, no anti-bacterial activity was observed in A. bunius against all the tested bacterial strains. But, at the concentration of $20 \mathrm{mg} / \mathrm{ml}$, A. bunius showed an inhibition zone of $8 \mathrm{~mm}$ against $P$. vulgaris and $9 \mathrm{~mm}$ against $S$. aureus, whereas no activity was observed against $B$. cereus and $E$. coli at the same concentration. Growth inhibition zones observed in $A$. dioica was $8 \mathrm{~mm}(20 \mathrm{mg} / \mathrm{ml})$ against $E$. coli and $14 \mathrm{~mm}(30 \mathrm{mg} / \mathrm{ml})$ against $S$. aureus and $P$. vulgaris. Aporosa dioica showed inhibitory zones of $9.5 \mathrm{~mm}$ at $10 \mathrm{mg} / \mathrm{ml}$ against $P$. vulgaris but no activity was observed at $10 \mathrm{mg} / \mathrm{ml}$ with other tested bacteria. Similarly, Saklani et al. (2012) studied the anti-bacterial activity of ethanolic extract of Rubus ellipticus fruit and reported $15 \pm 1 \mathrm{~mm}$ zone of inhibition against $E$. coli which is comparable to the results of the current study. The results reported for the inhibition zone of strains by Babahmad et al. (2018) ranged from $11.20 \pm 1.5 \mathrm{~mm}$ to $20.02 \pm$ $0.9 \mathrm{~mm}$ for gram-positive bacteria and from $10.2 \pm 1.2 \mathrm{~mm}$ to 11.35 $\pm 0.5 \mathrm{~mm}$ for gram-negative bacteria which are comparable to the values of the present study. The results of present study are in agreement with the findings of Qadir et al. (2015) who reported that the inhibitory zone of seed extracts of Anamirta cocculus against P. vulgaris, S. aureus, E. coli, K. pneumonia, and S. typhi that ranged from $5 \pm 1.10$ to $20 \pm 0.31 \mathrm{~mm}$.

The results revealed that all plant extracts were potentially effective in suppressing the microbial growth of food poisoning bacteria with variable potency. Eugenia operculata was the most effective extract retarding the microbial growth of $S$. aureus and $B$. cereus at all concentrations $(10,20$, and $30 \mathrm{mg} / \mathrm{ml})$ while the extract of $O$. alismoides was effective against $S$. aureus and E. coli. Aporosa dioica fruit was found to be effective only against
S. aureus. Other fruit extracts showed variable anti-bacterial activity against food poisoning bacterial strains. Grewia sapida exhibited inhibitory effect against all bacterial strains (B. cereus, $S$. aureus, E. coli, and P. vulgaris) at two concentrations (20 and $30 \mathrm{mg} / \mathrm{ml}$ ), whereas $A$. bunius was effective against two of them (S. aureus and P. vulgaris). Results of anti-bacterial activity of the five wild fruit extracts could suggest that $P$. vulgaris was the most resistant strain to fruit extracts followed by $E$. coli and B. cereus, whereas $S$. aureus was the most susceptible strains to the extracted fruits. Moreover, E. operculata and $O$. alismoides extracts were the most effective extracts and showed a strong anti-bacterial activity against food poisoning bacteria.

\section{Determination of $\mathrm{MIC}$ and $\mathrm{MBC}$}

The anti-bacterial activities in methanol extracts of five wild edible fruits against four species of bacteria were assessed by evaluating MIC values. It is observed from Table 1 that all the fruit extracts showed varying degrees of anti-bacterial activity against all tested strains. The MIC and MBC values of microbial strains were in the range from 7.5 to $<30 \mathrm{mg} / \mathrm{ml}$ and $15 \mathrm{mg} / \mathrm{ml}$ to $<30 \mathrm{mg} / \mathrm{ml}$, respectively, depending on the nature of the bacterial strains. Eugenia operculata showed the lowest MIC values $(7.5 \mathrm{mg} / \mathrm{ml})$ with respect to the two strains such as $B$. cereus and $S$. aureus. Ottelia alismoides also showed the lowest MIC values $(7.5 \mathrm{mg} / \mathrm{ml})$ against $E$. coli and $S$. aureus whereas A. dioica exhibited the lowest MIC value $(7.5 \mathrm{mg} / \mathrm{ml})$ only against $S$. aureus. On the other hand, G. sapida showed the lowest MIC value of $15 \mathrm{mg} / \mathrm{ml}$ against all the tested strains. MIC is defined as the lowest concentration of the plant extract that inhibits the microbial growth after 24 hours of incubation (Kitzberger et al., 2007). 
$\mathrm{MBC}$ is the minimum amount of plant extract to completely kill the respective microorganism after 24 hours of incubation on the freshly inoculated agar plates (Kitzberger et al., 2007). The lower $\mathrm{MIC}$ and MBC values indicate higher anti-bacterial activities (Cowan, 1999). The MIC values of the fruit extracts studied were in accordance with the results reported by Tshikalange et al. (2017). The methanol extract of Psidium sartorianum reported by Pio-Leon et al. (2013) had MIC value of $2 \mathrm{mg} / \mathrm{ml}$ and MBC value of $4 \mathrm{mg} / \mathrm{ml}$ against $S$. aureus which are lower than the MIC and MBC values of the present study. The MIC values of wild berry fruit species studied by Radovanovic et al. (2013) against several bacterial species ranged from 15.6 to $500 \mu \mathrm{g} / \mathrm{ml}$ and MBC values ranged from 31.2 to $500 \mu \mathrm{g} / \mathrm{ml}$ which are higher in comparison to the values of the fruits studied herein. Dua et al. (2013) reported MIC value of cumin extract effective against $E$. coli, $S$. aureus, P. aeruginosa, and B. pumilus that ranged from 6.25 to $25 \mathrm{mg} / \mathrm{ml}$ and these values are comparable to the results of the present study. Akinpelu et al. (2015) also reported crude and butanolic extracts of Persea americana against $B$. cereus and both the extracts exhibited anti-bacterial activity at concentrations of 25 and $10 \mathrm{mg} /$ $\mathrm{ml}$ with $\mathrm{MBC}$ values of 3.12 and $12.5 \mathrm{mg} / \mathrm{ml}$, respectively. In this study, G. sapida fruit extract showed potential bactericidal activity against the tested pathogenic bacteria (E. coli and P. vulgaris) with $\mathrm{MBC}$ value of $15 \mathrm{mg} / \mathrm{ml}$. Likewise, E. operculata also showed bactericidal activity against $B$. cereus and $S$. aureus. Aporosa dioica fruit also showed bactericidal activity against $S$. aureus and P. vulgaris with $\mathrm{MBC}$ value of $15 \mathrm{mg} / \mathrm{ml}$ while $\mathrm{MBC}$ value of A. bunius fruit reached to $<30 \mathrm{mg} / \mathrm{ml}$ against all the four tested strains which was less sensitive. The MIC values of Vitex doniana studied by Lagnika et al. (2012) ranged from 0.039 to $2.5 \mathrm{mg} / \mathrm{ml}$ and these values are lower than the MIC values of the fruits studied herein. The MBC values obtained in the study conducted by Mahboubi et al. (2015) ranged from 0.78 to $50 \mathrm{mg} / \mathrm{ml}$ and the $\mathrm{MBC}$ values obtained in the present study are within this range.

\section{Anti-nutritional contents of five wild fruits}

The tannin contents of the fruits were determined from the standard equation $\left(y=0.0009 x+0.0979, R^{2}=0.9821\right)$ obtained from the standard graph shown in Figure 1 . The phytate contents were also determined from the standard equation $\left(y=0.0003 x+0.0036, R^{2}=0.9549\right)$ obtained from the standard graph shown in Figure 2. The anti-nutritional contents of the five wild fruits are presented in Table 2. In this study among five wild

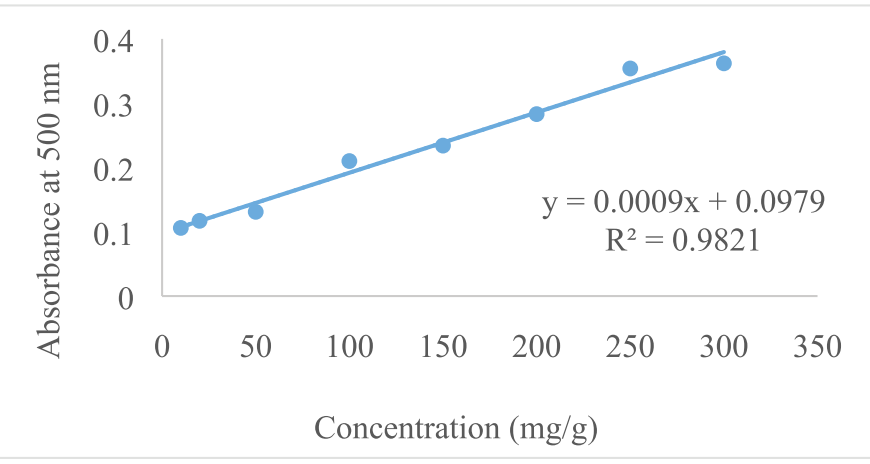

Figure 1. Standard graph of catechin for determination of tannin content. fruits, E. operculata and A. bunius showed low anti-nutritional factors, whereas $G$. sapida, A. dioica, and $O$. alismoides exhibited comparatively higher level anti-nutritional factors. The tannin contents in the tested samples ranged from $0.18 \pm 0.03 \mathrm{mg} / \mathrm{g}$ DW in E. operculata to $1.03 \pm 0.01 \mathrm{mg} / \mathrm{g} \mathrm{DW}$ in $O$. alismoides which are lower compared with the results observed in the fruits (7.5 mg/g) reported by Kozioc and Marcia (2004) and comparable to the values reported by Rout and Basak (2014). The tannin contents of the current study are higher than the tannin contents of Mordii whytii $(1.55 \pm 0.02 \mathrm{mg} / 100 \mathrm{~g})$ and Spondias mombin $(2.41 \pm 0.02 \mathrm{mg} / 100 \mathrm{~g})$ reported by Adepoju (2009). Umaru et al. (2007) also studied tannin contents of some wild fruits of Nigeria and reported the highest tannin content in Balanite aegyptiaca $(7.40 \% \pm 0.14 \%)$ and the lowest in Parkia biglobosa $(0.93 \% \pm 0.11 \%)$ and Phoenix dactylifera $(0.93 \pm 0.215)$. Tannins are well known to possess anti-diarrhoeal, anthelmintic, and antimicrobial activities and also possess astringent properties that accelerate wound healing (Morton, 2001). The level of phytate in the fruits was found the highest in $A$. dioica $(7.15 \pm 0.01 \mathrm{mg} / \mathrm{g})$ followed by $O$. alismoides $(5.53 \pm$ $0.01 \mathrm{mg} / \mathrm{g})$, E. operculata $(5.31 \pm 0.02 \mathrm{mg} / \mathrm{g})$, G. sapida $(4.73 \pm 0.01 \mathrm{mg} / \mathrm{g})$, and A. bunius $(3.79 \pm 0.02 \mathrm{mg} / \mathrm{g})$, and these results are comparable to that of 16 wild fruits reported by Rout and Basak (2014). Mahadkar et al. (2012) reported phytic acid content in wild fruits of Gmelina arborea $(0.02 \mathrm{~g} / 100 \mathrm{~g})$ and Oroxylum indicum $(0.04 \mathrm{~g} / 100 \mathrm{~g})$ which are lower in comparison to the results of the fruits studied herein. The phytate contents of five wild fruits (Table 2) are found higher than the levels of phytate in Thai fruits consumed by diabetic patients such as pineapple $(0.90 \mathrm{mg} / \mathrm{g})$, mango $(0.86 \mathrm{mg} / \mathrm{g})$, guava $(0.8$ $\mathrm{mg} / \mathrm{g})$, durian $(0.51 \mathrm{mg} / \mathrm{g})$, dragon $(0.39 \mathrm{mg} / \mathrm{g})$, and longan $(0.37 \mathrm{mg} / \mathrm{g})$ reported by Suree et al. (2004). In plant tissues, phytic acid is the major storage form of phosphorus. The daily average intake level of phytate for humans on vegetarian diets is $2,000-2,600 \mathrm{mg}$ while it is around 150-1,400 $\mathrm{mg}$ on mixed diets for inhabitants of rural areas in developing countries (Reddy, 2002). Oxalate content was found the highest in $O$. alismoides $(8.93 \pm 0.93 \mathrm{mg} / \mathrm{g})$ and the lowest in A. bunius $(3.15 \pm 0.45 \mathrm{mg} / \mathrm{g})$ which is comparable to the oxalate contents of wild edible fruits of Odisha (India) reported by Rout and Basak (2014). The higher level of oxalate content was reported in Ziziphus spichristi (16.20\%) by Umaru et al. (2007). Oxalate is a concern because it has undesirable effects on mineral availability. Diets rich in

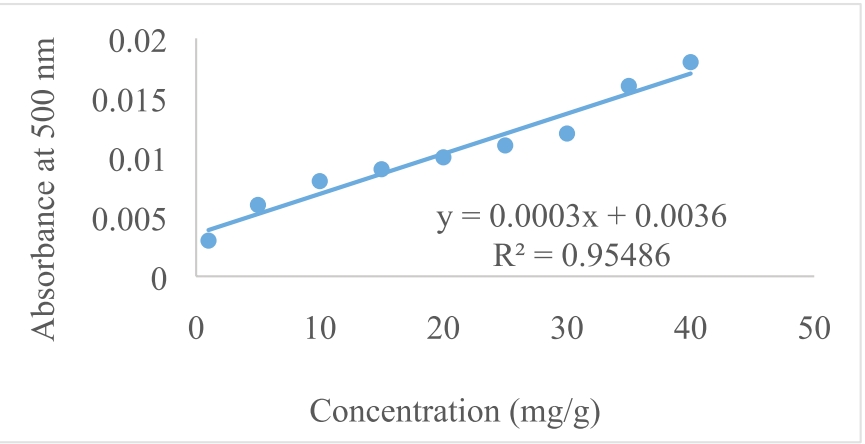

Figure 2. Standard graph of phytic acid for determination of phytate content. 
Table 2. Anti-nutritional contents of wild fruits in $\mathrm{mg} / \mathrm{g}$ dry weight (DW).

\begin{tabular}{lccccc}
\hline Plants & Oxalate & Tannin & Phytate & Saponin & Alkaloid \\
\hline G. sapida & $6.83 \pm 0.34^{a}$ & $0.35 \pm 0.03^{a}$ & $4.73 \pm 0.01^{a}$ & $0.09 \pm 0.02^{a}$ & $0.69 \pm 0.07^{a}$ \\
E. operculata & $4.15 \pm 0.38^{b}$ & $0.18 \pm 0.03^{a}$ & $5.31 \pm 0.02^{b}$ & $0.06 \pm 0.03^{a}$ & $0.56 \pm 0.02^{a}$ \\
A. dioica & $6.25 \pm 0.96^{a}$ & $0.91 \pm 0.03^{b}$ & $7.15 \pm 0.01^{c}$ & $0.13 \pm 0.02^{b}$ & $1.34 \pm 0.02^{b}$ \\
A. bunius & $3.15 \pm 0.45^{c}$ & $0.68 \pm 0.02^{a, b, c}$ & $3.79 \pm 0.02^{d}$ & $0.07 \pm 0.02^{a}$ & $0.31 \pm 0.06^{a}$ \\
O. alismoides & $8.93 \pm 0.93^{d}$ & $1.03 \pm 0.01^{b, c}$ & $5.53 \pm 0.01^{b}$ & $0.17 \pm 0.03^{b}$ & $1.68 \pm 0.02^{b}$ \\
\hline
\end{tabular}

Values were expressed as the mean of three replicates \pm standard deviation; the data with different letters in a column are significantly different from each other at $p<0.05$.

oxalates can increase the risk of renal calcium absorption which is linked to the formation of kidney stones (Chai et al., 2004). The level of saponins in the fruits ranged from $0.06 \pm 0.03 \mathrm{mg} / \mathrm{g}$ DW in E. operculata to $0.17 \pm 0.03 \mathrm{mg} / \mathrm{g}$ DW in O. alismoides. The saponin contents reported by Yadhu et al. (2011) in the seeds of black gram varied 9.2 to $21.4 \mathrm{mg} / \mathrm{g}$ which are much higher compared with the results of the present study. Gernah et al. (2007) also reported higher saponin content in African locust bean fruit $(17.80 \mathrm{mg} / 100 \mathrm{~g})$ compared with this study. Saponins are considered as harmful because of its toxicity and hemolytic activity (Campos-Vega et al., 2010) and high levels of saponins more than $10 \%$ could cause gastroenteritis manifested by dysentery and diarrhoea (Agbaire, 2012). Saponins are also known to have antimicrobial property (Maatalah et al., 2012). In present study, alkaloid contents varied from $0.31 \pm 0.06 \mathrm{mg} / \mathrm{g}$ in $A$. bunius to $1.68 \pm 0.02 \mathrm{mg} / \mathrm{g}$ in $O$. alismoides which are lower than the alkaloid contents of Ficus asperifolia (6.40 \pm $0.11 \mathrm{~g} / 100 \mathrm{~g})$ and Ficus sycomorus $(5.64 \pm 0.41 \mathrm{~g} / 100 \mathrm{~g})$ reported by Nkafamiya et al. (2010). Sango et al. (2016) also reported the higher concentration of alkaloids in Cleome gynandra (3.44\%) and Solanum nigrum $(15.160 \%)$ which are much higher compared with the current study. However, Anhwange et al. (2015) reported lower levels of alkaloids in some indigenous fruits which ranged from $0.0097 \mathrm{mg} / 100 \mathrm{~g}$ in P. americana to $0.1075 \mathrm{mg} / 100 \mathrm{~g}$ in Diallium guineense. Alkaloids are a group of organic compounds with nitrogen obtained from plants which are toxic to many living organisms. They are known to possess anti-bacterial, anti-spasmodic, and analgesic properties (Yadav et al., 2011). Alkaloids present in plants can prevent chordate and insects from eating it and they also cause infertility, neurological disorders, and gastro-intestinal upsets especially when consumed in excess (Olayemi, 2010).

\section{CONCLUSION}

In this study, it was found that all the five wild fruit extracts were effective in suppressing the microbial growth of food poisoning bacteria with variable potency. Ottelia alismoides and G. sapida fruit extracts are exhibiting the highest inhibition zone of $16 \mathrm{~mm}$ at $30 \mathrm{mg} / \mathrm{ml}$ against $E$. coli and $P$. vulgaris, respectively. Grewia sapida exhibited inhibitory effect against all bacterial strains, viz., B. cereus, S. aureus, E. coli, and P. vulgaris at concentrations of 20 and $30 \mathrm{mg} / \mathrm{ml}$. Ottelia alismoides, A. dioica, and $O$. alismoides fruits showed the lowest MIC value of $7.5 \mathrm{mg} / \mathrm{ml}$ against S. aureus with MBC value of $15 \mathrm{mg} / \mathrm{ml}$ indicating stronger anti-bacterial activities. In the current study, very high levels of anti-nutritional compounds were not observed in the fruits which may not be harmful for human consumption.

\section{REFERENCES}

Adepoju OT. Proximate composition and micronutrient potentials of three locally available wild fruits in Nigeria. African J Agric Res, 2009; 4(9):887-92.

Agbaire PO. Levels of anti-nutritional factors in some common leafy edible vegetables of Southern Nigeria. African J Food Sci Technol, 2012; 3(4):99-101.

Akindahunsi AA, Salawu SO. Phytochemical screening of nutrients and anti-nutrient composition of selected tropical green leafy vegetables. African J Biotechnol, 2005; 4(6):497-501.

Akinpelu DA, Aiyegoro OA, Akinpelu OF, Okah AI. Stem bark extract and fraction of Persea americana (Mill.) exhibits bactericidal activities against strains of Bacillus cereus associated with food poisoning. Molecules, 2015; 20:416-29.

Anhwange BA, Tyohemba RL, Tukura BW, Ogah P. Screening of some indigenous wild fruits for anti-nutritional factors. J Sci Res Rep, 2015; 5(3):220-7.

Awe IS, Sodipo OA. Purifications of saponins of root of Blighia sapida Niger. J Sci Food Africa, 2001; 16(3):201-4.

Babahmad RA, Aghraz A, Boutafda A, Papazoglou EG, Tarantilis PA. Chemical composition of essential oil of Jatropha curcas L. leaves and its antioxidant and antimicrobial activities. Ind Crops Prod, 2018; 121(1):405-10.

Brandi G, Amagliani G, Schiavano GF, De Santi M, Sisti M. Activity of Brassica oleracea leaf juice on foodborne pathogenic bacteria. J Food Prot, 2006; 69(9):2274-9.

Campos-Vega R, Loarca-Pina G, Oomah BD. Minor components of pulses and their potential impact on human health. Food Res Int, 2010; 43:461-82.

Chai W, Liebman M. Assessment of oxalate absorption from almonds and black beans with and without the use of an extrinsic label. J Urol, 2004; 172:953-7.

Cowan MM. Plant products as antimicrobial agents. Clin Microbiol Rev, 1999; 12:564-582.

Day RA and Underwood AL. Quantitative Analysis. 5th Edition, Prentice Hall Publication, Upper Saddle River, 1986.

Dua A, Gaurav G, Balkar S, Mahajan R. Antimicrobial properties of methanolic extract of cumin (Cuminum cyminum) seeds. Int $\mathrm{J}$ Res Ayurveda Pharm, 2013; 4(1):104-7.

Gernah DI, Atolagbe MO, Echegwo CC. Nutritional composition of the African locust bean (Parkia biglobosa) fruit pulp. Niger Food J, 2007; 25:190-6.

Griffiths DO. The inhibition of enzymes by extract of field beans (Vicia faba). J Sci Food Agric, 2000; 30:458-62.

Gyawali R, Ibrahim SA. Impact of plant derivatives on the growth of foodborne pathogens and the functionality of probiotics. Appl Microbiol Biotechnol, 2012; 95(1):29-45.

Jorgensen JH, Turnidge JD. Antibacterial susceptibility tests: Dilution and disk diffusion methods. In: Murray PR, Baron EJ, Jorgensen JH, Landry ML, Pfaller MA (eds.). Manual of clinical microbiology. 9th edition, American Society for Microbiology, Washington, DC, pp 1152-72, 2007.

Kitzberger CSG, Smamia J, Pedrosa RC, Ferreira SRS. Antioxidant and antimicrobial activities of shiitake (Lentinula edodes) 
extracts obtained by organic solvents and supercritical fluids. J Food Eng, 2007; 80:631-8.

Kozioc MJ, Marcia MJ. Chemical composition nutritional evaluation and economic prospects of Spondias purpurea (Anaracardiaceae). Econ Bot, 2004; 52:373-80.

Lagnika L, Amoussa M, Adjovi Y, Sanni A. Antifungal, antibacterial and antioxidant properties of Adansonia digitata and Vitex doniana from Bénin pharmacopeia. J Pharmacogn Phytochem, 2012; 4(4):44-52.

Lanciotti R, Gianotti A, Patrignani F, Belletti N, Guerzoni M, Gardini F. Use of natural aroma compounds to improve shelf-life and safety of minimally processed fruits. Trends Food Sci Technol, 2004; 15:201-8.

Maatalah MB, Bouzidi NK, Bellahouel S, Merah B, Fortas Z, Soulimani R, Saidi S, Derdour A. Antimicrobial activity of the alkaloids and saponin extracts of Anabasis articulate. E3 J. Biotechnol. Pharmaceutical Res, 2012; 3(3):54-7.

Mahadkar S, Valvi S, Rathod V. Screening of anti-nutritional factors from some wild edible plants. J Nat Prod Plant Resour, 2012; 2:251-5.

Mahboubi A, Asgarpanah J, Sadaghiqani PN, Faizi M. Total phenolic and flavonoid content and antibacterial activity of Punica granatum L. Var. pleniflora flower (Golnar) against bacterial strains causing food borne diseases. BMC Complem Altern Med, 2015; 15:366-73.

Morton J. Purple mombin fruits of warm climates. Miami Publishers, New York, 2001.

Nkafamiya II, Osemeahon SA, Modibbo UU, Aminu A. Nutritional status of nonconventional leafy vegetables, Ficus asperifolia and Ficus sycomorus. African J Food Sci, 2010; 4(3):104-8.

Obadoni BO, Ochuko PO. Phytochemical studies and comparative efficacy of crude extracts of some homeostatic plants in Edo and delta states of Nigeria. Global J Pure Appl Sci, 2001; 8:203-8.

Olayemi FO. A review on some causes of male infertility. Afr J Biotechnol, 2010; 9(20):2834-42.

Pio-Leon JF, Diaz-Camacho SP, Lopez-Lopez MA, UribeBeltran MD, Willms K, Lopez-Angulo G, Montes-Avila J, Delgado-Vargas F. Antibacterial activity of extracts obtained from the nanchi (Byrsonima crassifolia (L.) Kunth), arrayan (Psidium sartorianum (O. Berg) Nied.) and ayale (Crescentia alata Kunth) fruits. Bol Latinoam Caribe Plantas Med, 2013; 12:356-64.

Price ML, Van Scoyoc S, Butler LG. A critical evaluation of vanillin reaction as an assay for tannin in sorghum grain. J Agric Food Chem, 1978; 26:1214-8.

Qadir U, Paul VI, Ganesh P. Preliminary phytochemical screening and in vitro antibacterial activity of Anamirta cocculus (Linn.) seeds. J King Saud Univ Sci, 2015; 27(2):97-104.

Radovanovic BC, Andelkovic ASM, Radovanovic AB, Andelkovic MZ. Antioxidant and antimicrobial activity of polyphenol extracts from wild berry fruits grown in Southeast Serbia. Trop J Pharm Res, 2013; 12:813-9.
Reddy NR. Occurrence, distribution, content, and dietary intake of phytate. In: Reddy NR, Sathe SK (eds.). Food phytates, CRC Press, Boca Raton, FL, pp 25-51, 2002.

Rout P, Basak UC. Evaluation of anti-nutritional factors in sixteen wild edible fruits of Odisha, India. Int J Curr Sci, 2014; 13 : $34-42$.

Saklani S, Chandra S, Badoni PP, Dogra S. Antimicrobial activity, nutritional profile and phytochemical screening of wild edible fruit of Rubus ellipticus. Int J Med Aromat Plants, 2012; 2(2):269-74.

Sango C, Marufu L, Zimudzi C. Phytochemical, anti-nutrients and toxicity evaluation of Cleome gynandra and Solanum nigrum: Common indigenous vegetables in Zimbabwe. British Biotechnol J, 2016; 13(3): $1-11$.

Savoia D. Plant-derived antimicrobial compounds: alternatives to antibiotics. Future Microbiol, 2012; 7:979-90.

Suree N, Surat K, Akekachai N. Phytate and fiber content in Thai fruits commonly consumed by diabetic patients. J Med Assoc Thai, 2004 87(12):1444-6.

Tshikalange TE, Modishane DC, Tabit FT. Antimicrobial, antioxidant and cytotoxicity properties of selected wild edible fruits of traditional medicinal plants. J Herbs Spices Med Plants, 2017; 23(23):68-76.

Ugwu FM, Oranye NA. Effects of some processing methods on the toxic components of African breadfruit (Treculi aqfricana). African J Biotechnol, 2006; 5:2329-33.

Umaru HA, Adamu R, Dahiru D, Nadro MS. Levels of antinutritional factors in some wild edible fruits of northern Nigeria. Afr J Biotech, 2007; 6:1935-8.

Vaintraub IA, Lapteva NA. Colorimetric determination of phytate in unpurified extracts of seed and the products of their processing Anal Biochem, 1988; 17:227-30.

Yadav RNS, Agarwala M. Phytochemical analysis of some medicinal plants. J Phytol, 2011; 3(12):10-4.

Yadhu S, Satvir K, Gupta AK, Narinder K. Levels of nutritional constituents and antinutritional factors in black gram (Vigna mungo L. Hepper). Food Res Int, 2011; 44(2):621-8.

How to cite this article:

Islary A, Sarmah J, Basumatary S. Antibacterial property and anti-nutritional contents of five wild fruits of Assam, India. J App Pharm Sci, 2018; 8(12): 170-175. 